\title{
Review on Issues and Problems of Transferring Felda Land Ownership
}

\author{
Nohafizah Arifin (Corresponding author) \\ Department of Real Estate, Faculty of Geoinformation and Real Estate \\ Universiti Teknologi Malaysia, 81310 Johor, Malaysia \\ E-mail: hafizah1208@gmail.com \\ Khadijah Hussin \\ Department of Real Estate, Faculty of Geoinformation and Real Estate \\ Universiti Teknologi Malaysia, 81310 Johor, Malaysia \\ E-mail:khadijah@utm.my
}

Received: August 10, 2014 Accepted: November 2, 2014 Published: February 1, 2015

doi:10.5296/jmr.v7i2.6942 URL: http://dx.doi.org/10.5296/jmr.v7i2.6942

\begin{abstract}
Federal Land Development Authority (FELDA) in Malaysia has been a successful land development agency for the past fifty-eight years. FELDA was established on 1 July 1956, it is the main government instrument in reducing rural poverty and rewarding of land ownership on an economic scale. Land ownership under FELDA is unique and different from usual because FELDA lands are subject to the Land Act (Group Settlement Area) 1960 and other common practice of land ownership are subject to the National Land Code 1965 (NLC). Now, most of the settler had received their land title after completing their payment to the FELDA. However, most of the first generation FELDA is passing away by the day due to old age. This situation has lead to the issue in the process of transferring FELDA land ownership to the next generation. Therefore, the objective of this article is to review the issues in the transfer of FELDA land ownership to the rightful heirs based on the previous studies and identify the mechanism for distribution of inheritance in FELDA land that has been discussed. Data in this article are obtained through observation of literature review based on previous studies. Based on the review of previous studies, it is found that there are three main
\end{abstract}




\section{Macrothink}

Journal of Management Research

ISSN 1941-899X

2015, Vol. 7, No. 2

problems to overcome with regards to this subject namely heir, legal and administration issues. The findings of this article showed that the most of the settlers had chosen to appoint administrators as FELDA land distribution mechanism than giving ownership directly to any of the heirs agreed to. Thus, the future research is needed in order to find a better solution for the problems of transferring FELDA land ownership including the second and third generation. A new model is needed to secure FELDA land ownership and to ensure the interest of second generation FELDA will be secured.

Keywords: FELDA, Land ownership, Land Act 1960, Second generation 


\section{Introduction}

Federal Land Development Authority (FELDA) in Malaysia has been a successful land development agency for the past fifty-eight years. FELDA was established on 1 July 1956 under Land Development Act 1956, it is the main government instrument in reducing rural poverty and rewarding of land ownership on an economic scale. The establishment of Felda was inspired from the idea brought up by the first Deputy Prime Minister at the time, Tun Abdul Razak bin Hussein with several objectives which is to channel financial aid to state governments, take over a number of state government projects, to systematically open new undeveloped lands and provide land ownership opportunities to Malaysians who were without any (Tunku Shamsul Bahrin, P.D.A. Parera \& Lim Heng Kow, 1992).

The main objective of the establishment of Felda is to resettlement and rehabilitation scheme to eradicate poverty and expedite rural development for smallholder. It served as one of the Federal Government's tools to help eradicate poverty and restructure the community by putting people do not have the land to the Felda land scheme has been developed (Adibah Awang, 2008; Khamis Mat Som, 2003). Felda's role has also stated in the Land Development Act 1956 section 3 (2) that "It shall be the duty of the Authority to promote and assist the investigation, formulation and carrying out of the developments and settlement of land in the Federation".

In order to open new undeveloped lands and resettlement the poor based on Felda scheme, hence government agreed to draft the Land (Group Settlement Area) Act 1960 or better known as GSA Act. The purpose of this Act is to ensure uniformity of law and policy in respect of the establishment of group settlement areas and the conditions of alienation and occupation of land in such areas. This Act also purpose to improve the socio-economy and living standard of the rural community by allocating pieces of land to selected settler to work on earn extra income as has been pointed out by the late Tun Abdul Razak Hussein on 27 April 1960.

Ownership of the land through the GSA Act is through the concept of giving land to the settler of the deferred payment scheme such rental property or hire-purchase. All payments must be paid to the State Government will be payment first by government agencies, whether Felda or other agency managers. While the people were given the opportunity to make progressive payments until all debts are fully settled which include the premium on land, development costs, survey fees and others (Arif Simeh, 2001). At the end of the repayment of the consolidated annual charge, each settler will be issued with a land title. This normally takes about 15 years or more (Tunku Shamsul Bahrin \& Lee Boon Thong, 2006). Each settler was given 6-10 acres of agricultural land (2.4-4 hectares) as well as another half an acre for setting up their home based on GSA Act. At present, most of the settlers (first generation) have received title to the land after they managed to repay all its debts to the Felda. 
Table 1. Ownership of Settlers Who Was Registered Until 31 December 2006

\begin{tabular}{|c|c|c|c|}
\hline \multirow[t]{2}{*}{ State } & \multicolumn{2}{|c|}{ Number of Settlers by Type Plants } & \multirow{2}{*}{$\begin{array}{c}\text { The total number of } \\
\text { settlers }\end{array}$} \\
\hline & Rubber & Oil Palm & \\
\hline Selangor & 783 & 1,364 & 2,147 \\
\hline Perak & 1,504 & 2,356 & 3,860 \\
\hline Kedah & 1,957 & 0 & 1,957 \\
\hline Terengganu & 629 & 3,438 & 4,067 \\
\hline Melaka & 1,063 & 273 & 1,336 \\
\hline Negeri Sembilan & 7,910 & 2,086 & 9,996 \\
\hline Johor & 4,648 & 12,738 & 17,386 \\
\hline Pahang & 5,652 & 26,234 & 31,886 \\
\hline Kelantan & 0 & 627 & 627 \\
\hline Total & 24,146 & 49,116 & 73,262 \\
\hline
\end{tabular}

Based on the table above, until December 2006 a total of 73,262 settlers have acquired title. Besides that, it appears the total number of titles issued was 24,146 settlers and rubber plantations and the remaining settlers of 49,116 for oil palm plantation.

It has been proven that the intention of the late Tun Abdul Razak Hussein, the "land for landless" has been achieved through the establishment of Felda (Rokiah Talib, 2009).Titles will be awarded after all loans and fees paid to the Felda and the land will be returned to the State Government. Titles will be issued individually for a lease period of 99 years.

\section{The issues in the transfer of FELDA land ownership to the rightful heirs}

Ownership of Felda land was different and exclusivity because its land is subject to the provisions under the Land (Group Settlement Area) Act 1960 or GSA Act which cannot be held by more than two people (Tunku Shamsul Bahrin et al., 1992). Other than that, the names of heirs and beneficiaries cannot be registered on the title which totally different with the land under National Land Law Code 1965 (NLC). Major problems have existed due to restrictions in the transfer of felda land ownership which give effect to the beneficiaries including the fate of the second generation of Felda. The increasing number of children in each family pose a serious problem in terms of inheritance should the original settler pass away (Nurwati Badarulzaman \& Fatimah Hassan, 2005).

The latest data recorded by the Inheritance Administration Section shows that almost $40 \%$ of all inheritance land ownership subject to the GSA Act was not successfully transferred beyond the letter of administration issuance stage. Based on Zulkifli Mohamad (2011), shows that from a total of 616 of the original settlers, 322 have already passed away and 160 of them passed without having applied for ownership transfer in early 2002 in the Lurah Bilut Felda. From that research it was found out that $60.62 \%$ of the cases are caused by disputes within the family themselves. In general, over 14,138 deaths were recorded by the Felda headquarters up until 23 May 2007. Based on Nasrul Hisyam Nor Muhamad and Norazila Mat Hussain (2013), the incidence of fraud and disputes among heirs, and 
other issues have also contributed to the problems in the distribution of felda land ownership. In addition, there are thousands of land title is still registered with the name of the owner who has died and has not been transferred to a rightful heirs. These findings indicate no action in the transfer of land to heirs entitled. This statement is supported when more than one million cases claim inheritance with the reach RM38 billion still outstanding for not managed by the beneficiary (Norazila Mat Hussin \& Nasrul Hisyam Nor Muhamad, 2012).

Upon closer observation, it can be seen that researches on the issues in the transfer of Felda land ownership are still limited, as compared to land transferring issues under the National Land Code. Therefore, the objective of this article is to review the issues in the transfer of Felda land ownership to the rightful heirs based on the previous studies through of literature review. This article will also try to identify the mechanism for distribution of inheritance in Felda land that has been discussed.

\subsection{Restriction of Land (Group Settlement Area) Act 1960}

Land (Group Settlement Areas) Act 1960 was enacted in 1960 in accordance with the provisions under article 76 of the Federal Constitution. This Act was formulated to standardize the implementation of the policy for all states in the peninsula, namely in terms of policy and executive powers granted to the State Authority (Khamis Mat Som, 2003). The main goal of the drafting of the Act is to establish a new settlement planned the opening in group's settlement areas, including the opening of plantations by the implementing agencies as a source of economic. The other objective of this Act is to eradicate poverty and distribute land to the landless population and create a harmonious society and viable (Zulkifli Mohamad, 2010). However, the alienation of land given to settlers is not absolute. This is because there are restrictions that must be observed by the GSA Act. Although land title deeds have been obtained, the settlers cannot independently make transactions on land is like selling, lease or transfer. There are various restrictions that must be followed under the GSA Act. The restrictions are as follows:

i. Section 14 does not allow land settlers registered more than two owners who think as co-owner

ii. Section 15 of the land cannot be subdivided or leased in part or in whole

iii. Section 7 (3), also limits the holding for the city as a residential, public, commercial and other uses as approved by the State government

Restrictions under this Act is consistent with the objectives of Felda in 1965, namely to maintain the Felda land as agricultural land that is competitive and economically (Mohd Yassin Mohd Yusuf, 2010). Restrictions contained in section 14 and section 15 of the Act have created problems for distribution Felda land ownership to the right heirs included in the process of distribution of inheritance Felda settlers. These restrictions resulted beneficiary is unable to perform distribution of title is not like other lands that are not bound to GSA Act. Due to this restriction, the Felda land could not divide according to faraid but only allows only two owners registered in the ownership or the appointment of an administrator only. The division of inheritance that used faraid is based on the outcome of land settler estates. 
According to the study Norazila Mat Hussin and Nasrul Hisyam Nor Muhamad (2012), there are still many settlers who have not changed the name from the original settler to the rightful heirs in the distribution of land ownership due to the disputes and dissatisfaction by certain parties in the election of the beneficiary. In the process of transition of power to the heir settlers, many issues related to inheritance have been in existence. Disputes among heirs usually occur in two situations, namely when the death of settlers and when the process of felda land distribution. Disputes that occur when the settlers died were to determine the beneficiaries has the right to land settlers which can manage the land and dividing the outcome of the Felda land. While disputes that occur during the process of land distribution Felda arise when there is no cooperation for discussion among the beneficiaries in distribution of ownership. Therefore, an administrator will be appointed which should be someone who can be trusted, honest and responsible and appointed with the consent of between the beneficiaries to administer and manage the inhertitance of Felda land. Role of administrator is to manage the estate and distribute the proceeds to the beneficiaries under Faraid or Distribution Act 1958 (Act 300) or by consensus as agreed by all beneficiaries (Wan Abdul Halim Wan Harun, 2012).

However, there are some administrators do not trust in the distribution of outcome to other beneficiaries. An administrator has changed the ownership of land by registering the name without knowledge of the other heirs and made a declaration of oath that no other heirs are entitled to the above land. In addition, there are also administrators who make until the land auctioned bank loans due administrators are not able to repay the loan. This situation shows the failure of administrators in managing the property settlers according to the conditions of appointment of administrator under the Small Estates (Distribution) Act 1955.This issue has led to the appointment of two joint administrators to administer the inheritance of deceased persons involved or the register of title under the Land (Group Settlement Areas) Act 1960. Appointment of two administrators will make them more responsible for any decisions in the production and distribution of the deceased's property and interests requires a joint decision.

According to the results of studies that have been done in Felda Taib Andak by Nasrul Hisyam Nor Muhammad and Norazila Mat Hussain (2013), the findings show that the majority of respondents $(92.3 \%)$ agree that the provisions of the Act or restrictions Land (Group Settlement Areas) Act 1960 in the distribution of property rights is a better solution to maintain economical of Felda land and can continue their livelihood settlers. The results of this study support the real main purpose of the restriction is to avoid Felda land becomes uneconomic and too many of ownership when land parcels in the subdivision to be too small (Kamarul Zaman Habib, 1988).

\subsection{Causes of Delay in Distribution of Felda Land Ownerhip}

Issues concerning Felda inheritance lands occur upon the death of a settler same with the issues of distribution Felda land ownership. More and more settlers are passing away by the day due to old age. Based on the previous study Zulkifli Mohamad (2010), in Felda Lurah Bilut in total 273 respondents were involved in the study which includes $54(19.8 \%)$ are first generation settlers, $176(64.5 \%)$ are second generation settlers, whereas $26(9.5 \%)$ are third 
generation settlers, which means that a majority of the respondents are second generation settlers, who are the children and beneficiary of the original group. According to the findings of this study, there are three main causes of delay in distribution of Felda ownership which are family dispute, the lack of information provided by authorities and lack of understanding of the procedure.

The main cause of the division of inheritance Felda unresolved due to dispute between the beneficiaries. Highest response was disagreement and the consent between the siblings to appoint a right heir for the purpose of registration of land titles. This is because the Felda land ownership is restricted to only two names to be registered in the title. Beneficiaries are often not present when the court settlement hearings due to their attitude each other with suspicion and the consent of all parties should be reached before the transfer takes place. They also said due disagreement, siblings argue to seize the Felda land. Therefore, if the matter remains unresolved, the administrator is appointed as trustee of Felda inheritance lands. However, there are administrators who do not trust in the performance of their duties and thus causing a delay in the distribution of Felda land ownership.

In addition, the lack of information regarding the division of Felda land by Felda agencies is also one of the causes of delay in the distribution of Felda land to the right heirs. Most beneficiaries still do not understand the law includes restrictions Felda land ownership in the provisions of the GSA Act. Party beneficiary was not sure about the procedures in distribution of inheritance land. Most beneficiaries claimed division process involves a long process, complicated and requires a long period of time. The delay in the distribution of land ownership Felda can be summarized in Table 2. 
Table 2. Causes of Delay in Transfer Ownership

\begin{tabular}{|c|c|}
\hline Causes of delay & Percentage \\
\hline $\begin{array}{l}\text { Family disputes: } \\
\begin{array}{ll}\text { - } & \text { disagreement between siblings } \\
\text { - } & \text { feud between siblings } \\
\text { - } & \text { lack of respect for the eldest sibling } \\
\text { - } & \text { failure to attend court settlement hearing } \\
\text { - } & \text { failure of beneficiaries to meet and discuss together } \\
\text { - } & \text { lackadaisical attitude } \\
\text { - } & \text { envy } \\
\text { - } & \text { unscrupulous registered beneficiary } \\
\text { - } & \text { failure of eldest sibling to split the returns }\end{array}\end{array}$ & $60.62 \%$ \\
\hline $\begin{array}{l}\text { Lack of information: } \\
\text { - } \text { lack of information provided by Felda } \\
\text { - } \text { no point of reference } \\
\text { - } \text { lack of understanding on Felda laws } \\
\text { - } \text { unfair rulings }\end{array}$ & $18.89 \%$ \\
\hline $\begin{array}{l}\text { Problems with the procedure: } \\
\text { - } \text { red tape } \\
\text { - } \\
\text { - } \\
\text { complicated and time-consuming process } \\
\end{array}$ & $8.66 \%$ \\
\hline Failure to come up with a will & $3.93 \%$ \\
\hline Polygamy & $3.14 \%$ \\
\hline Third party involvement & $1.57 \%$ \\
\hline Inability to afford other beneficiaries portion & $1.57 \%$ \\
\hline Heirless estate owner & $1.57 \%$ \\
\hline Percentage & $100 \%$ \\
\hline
\end{tabular}

From the result of this table, we can conclude that majority of the respondent $(60.62 \%)$ stated that family dispute is the main causes to the delay of transferring the Felda land ownership. This means that a majority of these problems are caused by the failure of the beneficiaries to meet and discuss together. However, in contrast to the results of studies that have been done by Norazila Mat Hussin and Nasrul Hisyam Nor Muhamad (2012), the majority of respondents (94.7\%) agreed that the cause of the delay in the distribution of Felda land is due to polygamy. When settlers would marry more than one, occurrence of neglect of responsibilities for his first wife and children in case of divorce. This is because the ownership of the land is registered in the name of settler which is their husbands and his wife will lose the right to the ownership of the land. Therefore, the amendment of the GSA Act which allows the wife done as a co-holder in Felda land which gives the guarantee of rights 
to the wife which are already working with Felda land.

\section{Mechanism for Distribution of Inheritance in FELDA Land}

Mechanism for distribution of inheritance in Felda land has its own unique because it differs from the common distribution of inheritance mechanism. Felda land distribution mechanism is divided into three methods either directly distribution, appoint an administrator or sell the property.

a) Directly distribution

Directly distribution is a method of consensus among the heirs. Heirs surrendered their parts to a beneficiary only. Distributions by mutual agreement are form of refusal without consideration. This situation can be seen when the settlers left the children and a wife, then the children give up their right to their mother. Furthermore there is also refusal to grant of cash. Then the property is evaluated by the proportion that should be obtained by the heirs demanded either in accordance with the law faraid or division. (Mohd Yassin Mohd Yusuf, 2010). Directly distribution is a mechanism that can retain ownership of the land economically without subdivision to obtain maximum productivity of estate. However, this method is difficult to implement because everyone of heir want their land right under their names. This method also requires the consent of all beneficiaries who are entitled to such property in accordance to faraid.

b) The appointment of administrators

The second mechanism is to appoint an administrator to manage the farm produce and divide it to the beneficiaries according to faraid, or as agreed by the heirs. Administrators do not have any advantages compared with other beneficiaries as a result of inheritance will still be divided equally among them. Administrators are responsible for explaining the tax, keeping operating production and divide the proceeds among the heirs. Felda not directly involved in the distribution of inheritance production except by the court order. Order the appointment of an administrator is only temporary and if there is a request repetition of the trial, the order can be cancelled by appointing a new administrator or other commands as appropriate. The administrator is appointed by the Small Estate Distribution in Form F. Based on previous studies Nasrul Hisyam Nor Muhamad and Norazila Mat Hussain (2013) the majority of respondents, $87.6 \%$ agreed that Felda land distribution mechanism is better to appoint an administrator among beneficiaries to manage the land and not to give ownership to one of the members beneficiaries.

c) The sales order

The last way is to sell the Felda land among heirs itself. The proceeds raised will be distributed to rightful heir. If the beneficiary is unable to pay the value of the land, then the buyer will be sought. The last step was taken due to the absence of consensus and agreement among the heirs to appoint administrators. Based on this method of evaluating the land done and if the beneficiary is able to pay the land value is fully 
done to the transfer of ownership in the name of the beneficiary. However, this mechanism is rarely used because of the absence of a beneficiary who can afford to pay the other heirs because of the high land price valuation. If no heirs who can afford to pay and beneficiaries are not getting cooperation for distribution of title and the appointment of administrators proposed to them to sell the land to FELDA. If all agree to sell to the FELDA the results of the sale will be distributed to all beneficiaries in accordance with the respective divisions either through faraid or equitable distribution according to the agreement between the heirs.

This mechanism is coincided with the results of the Muzakarah Fatwa Committee of the National Council for Islamic Religious Affairs Malaysia was the 38th meeting held on June 21, 1995 regarding inheritance in Felda. They decided that the practice is implemented planned Felda on inheritance property by the Land Act 1960 is not contradictory because the agreement was made to put a nominee on the consent of all parties involved (Zulkifli Mohamad, 2011).

\section{Conclusion}

As a conclusion, the issues in the transfer of Felda land ownership to the rightful heirs occur in the two situation namely when the death of settlers and when the process of Felda land distribution. More and more settlers are passing away by the day due to old age and many of them passed away without having applied for ownership transfer. There are three main factor were identified as the cause of the delay and failure in transferring the land ownership which is heir, legal and administration issues. However the main causes of the delay in transferring Felda land ownership is due to dispute between the beneficiaries. This dispute arise they was disagreement of registration Felda land. In addition, the restriction of GSA Act is better solution to maintain the Felda land as agricultural land that is competitive and economically. Most of the settlers agreed that to appoint an administrator as a mechanism in land distribution. Due to the critical issues of transferring Felda land ownership, the future research is needed in order to find a better solution for this problem including the second and third generation of Felda. A new model is needed to secure Felda land ownership and to ensure the interest of second generation of Felda will be secured.

\section{References}

Addan Din (1989). The Need for Integrated Second Generation Planning and Policy Implementation in Felda Land Development and Settlement Programme. Environment Science, 12(2), 45-64.

Adibah Awang (2008, December). A Critical Assessment of Provision of the Federal Constitution With Regard to Federal-State Relationship on Land Law. Paper Presented at the International Conference on Contemporary Issues of Law Syariah \& Legal Research, Faculty of Syariah, University of Jordan, Amman.

Arif Simeh (April, 2001). The Case Study on The Malaysian Palm Oil. Regional Workshop on Commodity Export Diversification and Poverty Reduction in South and South-East Asia, 
Bangkok, Thailand.

Bahijah Md Hashim, Adilah Abdul Hamid, Mat Saad Abdullah, Rohana Alias \& Sarina Muhamad Noor (2009). Socio-Economic Issues among Felda Settlers in Perlis. Asian Culture and History, 1(2), 113-117. http://dx.doi.org/10.5539/ach.v1n2p113

Kamarul Zaman Habib (1998). Sistem Pengurusan dan Pembahagian Pusaka Khususnya Pembahagian Harta Pusaka Kecil. Ridzuan Awang, ed., Undang-Undang dan Pentadbiran Harta Orang-Orang Islam di Malaysia. Kuala Lumpur: Al-Rahmaniah.

Khamis Mat Som (2003). Akta Tanah (Kawasan Penempatan Berkelompok) 1960 \& Pembangunan Masyarakat. Seminar Pentadbiran dan Perundangan Tanah. Institut Tanah dan Ukur Negeri Perak, Malaysia, 15-16 Disember 2003.

Mohd Yassin Mohd Yusuf (2010). Pentadbiran Harta Pusaka GSA Dalam Sistem Pentadbiran Tanah Negara. Master's Thesis. Universiti Teknologi Malaysia.

Nasrul Hisyam Nor Muhamad, \& Norazila Mat Hussain (2013). Pembahagian Harta Pusaka Felda: Perspektif Masyarakat Islam Felda Taib Andak. Journal Technology UTM Social Sciences, 66(1), 27-33.

Norazila Mat Hussain \& Nasrul Hisyam Nor Muhamad (2012). Mekanisme Pembahagian Harta Pusaka Tanah Rancangan: Kajian di Felda Taib Andak, Kulai Johor. Jurnal Kanun, $1(25), 1-21$.

Nurwati Badarulzaman \& Fatimah Hassan (2005, September). Feldajaya As a Sustainable City for Felda Settlers: Will it Work? An Exploratory Study. Paper Presented at the International Conference of The Asian Planning Schools Association, Penang, Malaysia.

Pekeliling Ketua Pengarah Tanah dan Galian Persekutuan Bilangan 12/2009. (Pengeluaran Surat Kuasa Tadbir (Letter of Administration) di bawah Akta Harta Pusaka Kecil (Pembahagian) 1955 Bagi Hakmilik dan Daftar Pegangan di Bawah Akta Tanah (Kawasan Penempatan Berkelompok) 1960).

Rokiah Talib (2009). National Building The Felda Model. Retrieved Mei 14, 2014, from http://www.unirazak.edu.my

Tunku Shamsul Bahrin, Lee, Boon Thong. (1998). FELDA: 3 Decades of Evolution. Kuala Lumpur: FELDA.

Tunku Shamsul Bahrin, P.D.A. Parera \& Lim Heng Kow (1992). Kemajuan Tanah dan Penempatan Semula di Malaysia. Kuala Lumpur: Dewan Bahasa dan Pustaka.

Wan Abdul Halim Wan Harun (2012). Isu Pembahagian Harta Pusaka Orang Islam dalam Konteks Perundangan Malaysia. Retrieved from http://www.islam.gov.my

Zulkifli Mohamad (2010). Penyelesaian Isu Harta Pusaka Tanah Rancangan Felda: Kajian Kes Felda Lurah Bilut Bentong, Pahang Darul Makmur. Ph.D Thesis. Universiti Malaya.

Zulkifli Mohamad, Johari Talib \& Ruzman Md.Noor (April, 2011). Issues of Land 


\section{Macrothink}

Journal of Management Research

ISSN 1941-899X

2015, Vol. 7, No. 2

Inheritance form Felda Settler's Perspective: A Case Study Among Settlers in Lurah Bilut, Bentong Malaysia. Paper Presented at the International Business Research Conference, Sydney, Australia.

\section{Copyright Disclaimer}

Copyright for this article is retained by the author(s), with first publication rights granted to the journal.

This is an open-access article distributed under the terms and conditions of the Creative Commons Attribution license (http://creativecommons.org/licenses/by/3.0/). 